netres, which is fully as many as the scale can bear in some areas. Principal railways are shown as red lines and selected roads as red dotted lines. Political boundaries as in 1938 are marked and there are also shown oil fields, pipe lines, ancient sites, deserts, marshes and glaciers. No submarine relief is shown : water is blue. Names of countries and principal rivers and towns are in black. An edition with names in Arabic is to be published. The present sheet (No. 1), flat or folded, costs 5s., or, flat, with the outline edition of No. 2 and No. 3, which are not sold separately, $8 s$.

\section{Sir Robert Kane}

UNDER the auspices of the Chemical Society of University College, Cork, Mr. D. O. Raghallaigh has recently issued an interesting booklet of forty-three pages dealing with the life and work of Sir Robert Kane (1809-1890), a pioneer of chemistry and of industry in Ireland. Kane studied medicine at Trinity College, Dublin, and became professor of chemistry at the Irish Apothecaries' Hall at the age of twenty-two. After his appointment to the chair of natural philosophy at the Royal Dublin Society in 1834, he published his important work on ammoniacal compounds of mercury, copper and zinc. This was followed in 1840 by a research on the colouring matter of lichens, and soon afterwards Kane was elected F.R.S. His "Elements of Chemistry", completed in 1843, achieved fame as a standard text-book. $\mathrm{He}$ took far-sighted views of Irish industries and agriculture; for example, he directed attention to the chemical potentialities of Irish peat and potatoes, and depicted the Shannon Valley as the future industrial centre of Ireland. In organic chemistry he accomplished the first synthesis of a cyclic compound (mesitylene) from an open-chain one (acetone). In 1845 Kane became the first president of the new Queen's College, Cork, and in the following year he was knighted for his services to science and Irish industry. After his resignation of the presidency in 1873 he became first dean of the Royal College of Science for Ireland, and later he was appointed vicechancellor of the Royal University. One of Kane's sons commanded H.M.S. Calliope in the historic escape of this ship from Samoa Harbour during the hurricane of March 15, 1889.

\section{Wood-Pigeon Investigation}

THE third Bulletin of the Wood-pigeon Investigation, issued by the Edward Grey Institute of the University of Oxford, covers some of the findings of the past nesting season, and the expansion of the investigation to have 500 observers recording 250 birds a month next breeding season, thus recording more than a million birds. In some parts of Great Britain during 1942 the birds were very sparse with only one or two nests in a hundred acres, and in others their nests were sulficiently concentrated to show definite breeding colonies with preference for certain areas. The most densely populated haunts were young spruce plantations. At the peak of the breeding season in August (it is much later than with most birds) these dense haunts had as many as twenty nests in four acres. At the end of September there were still 10-20 nests occupied in some plantations. Many districts had more occupied nests in July than in June.

It is hoped to gain a better knowledge of the distribution of the nesting colonies throughout Great
Britain in order to understand how they came to exist. The life of a wood-pigeon is long, but it is desired to know how long and how it varies with different types of woodland. The breeding season of the wood-pigeon does not necessarily coincide with that of other woodland birds. The possible connexion between late breeding and the formation of colonies is to be investigated. In the winter countryside, as in the nesting season, the wood-pigeon population is not evenly distributed. The filling in of record cards of winter flocks can give their distribution month by month, as well as their autumn, winter and spring movements, and a seasonal guide to feedinggrounds and flock sizes, favourite feeding hours and the relative number of stock doves feeding in the flocks. A collection of photographs is also being built up of nests, crop damage, and 'colony' woods.

\section{Biology of Oysters}

THE oysters of Australia are being thoroughly investigated by the Division of Fisheries, Council for Scientific and Industrial Research. In the first of the series of pamphlets on the biology and cultivation of oysters in Australia, G. A. Kesteven wrote on some economic aspects (Pamphlet No. 105 ; 1941). A more recent publication, in two parts, is by $\mathrm{G}$. Humphreys (2. A Note on the Calcium Content of Some East Australian Waters; 3. Biochemistry of the Proximal Constituents. Commonwealth of Australia. Council for Scientific and Industrial Research, Division of Fisheries. Report No. 7. Pamphlet 111. Melbourne, 1941). The calcium content of a number of oyster-growing waters has been investigated and the relation between condition and the fluctuation in the proximate constituents of the oyster, namely, carbohydrate fat and protein. It is concluded that there is no essential difference in calcium content between waters where oyster growth is normal and waters where only stunted growth appears. Opinions differ as to the role of glyeogen in the oysters, some maintaining that it determines fatness, others that it is a reserve food material. The author shows that the latter view is correct, for the fattest oysters occur just before spawning when the glycogen percentage is at its minimum. The idea, supported by recent investigators, that glycogen is stored as a reserve food material and is used for the formation of gonad products which do not consist of glyeogen is borne out by the figures presented, in which it is seen that for healthy oysters the glycogen percentage is in the range 3-7 during most of the year, but that just when the oysters are about to spawn, the value is below 2. It is found that oysters can be dried with no loss of glycogen or protein.

\section{Impregnating Varnishes}

W. J. KIERNAN points out in a recent article (Bell Lab. Rec., 20, No. 12 ; August 1942) that until the recent development of synthetic resins and drying oils the impregnants applied to coils contained linseed or china-wood oils and natural resins, and that they 'set' by surface oxidation, leaving the interior in a semi-fluid state. Fatty acids were usually present in the unset portion, sometimes in sufficient strength to corrode copper. Varnishes made with synthetic resins of the phenol-aldehyde type polymerize on drying rather than oxidize, and produce a solid state throughout their mass. Corrosive tendencies are negligible or entirely absent 
because of their complete setting and low acid content. When thoroughly dried by baking at high temperatures, they are no longer thermoplastic. This allows coils to operate at higher temperatures without softening the impregnating material and permits substantial savings by reducing the size of the coils. The penetrating power of these synthetic resins and their high dielectric strength make them particularly valuable for high-voltage circuits where corona discharges might occur and, by oxidizing the nitrogen, produce nitric acid which breaks down the coil insulation. Retardation coils and power transformers of several types, designed for telephone apparatus, are now being impregnated on a production basis with synthetic resin varnishes. The results indicate advantageous possibilities for their wider use.

\section{Tuberculosis Control in Argentina}

According to Dr. Hugo J. D'Amato, secretary of the National Department of Health of Argentina (Bol. Of. San. Panamer., 21, 772; 1942), family contacts have been examined in the last few years at the tuberculosis dispensaries of this department in order to discover unrecognized cases. As this procedure, however, did not include extra-familial contacts a new organization is being planned which will involve systematic and repeated examinations of the entire population. At present all public employees and all applicants for Government positions have to undergo clinical and radiological examinations of the thorax as well as tuberculin tests. Of 10,863 persons examined 104 were rejected and $5 \mathrm{I}$ were accepted with a temporary certificate while under treatment. Only six of the 10,708 applicants declared to be healthy or 60 per 100,000 have developed tuberculosis in the course of two years, whereas before examination was made compulsory the rate of infection was 520 per 100,000. In August 1941 the National Commission of Tuberculosis was created, which besides centralizing the administration of the tuberculosis control campaign, has power to propose measures regarding salaries, housing, nutrition and industrial hygiene.

\section{Earthquakes Registered in Switzerland}

During July and August 1942, thirty earthquakes were registered by the instruments at the Swiss observatories of Zurich, Chur, Basel and Neuchâtel (Swiss Earthquake Bull., No. 146 and No. 147). The distant earthquakes have, for the most part, been mentioned previously in the columns of NaTURE, but the local earthquakes have not. On July 1 an earthquake was felt with intensity $V$ (Rossi-Forel scale) in the Pays d'Enhaut. It was registered at Zurich at $23 \mathrm{~h} .43 \mathrm{~m} .13 \cdot 3 \mathrm{~s}$., the epicentre being some $135 \mathrm{~km}$. distant. On July 17 an earthquake was registered at Chur at $10 \mathrm{~h} .27 \mathrm{~m} .08 \cdot 8 \mathrm{~s}$., which had its epicentre in the Schwäbische Alb, and on July 18 an earthquake registered at Basel at $15 \mathrm{~h} .46 \mathrm{~m}$. $08 \cdot 3 \mathrm{~s}$. had its epicentre less than $10 \mathrm{~km}$. to the north-west of that station. The earthquake of August 27, registered at Zurich at $11 \mathrm{~h} .11 \mathrm{~m} .21 .9 \mathrm{~s}$. , had its epicentre $70 \mathrm{~km}$. from that station and was felt in the neighbourhood of the Brünig and Lungernsee. Finally, the earthquake of August 28, registered at Zurich at $11 \mathrm{~h} .28 \mathrm{~m} .58 \cdot 4 \mathrm{~s}$, had its epicentre $71 \mathrm{~km}$. from that place and was felt with intensity $\mathrm{V}$ in the neighbourhood of the Hohenstollen.

\section{An Important Binary Star System}

Dr. R. M. Petrie, of the Dominion Astrophysical Observatory, Victoria, B.C., reports the discovery of another sub-dwarf star, a component of the binary system HD 144208-9 (Sky and Telescope, August). The primary in the system is of class $G$ and the dwarf is of class $A$ and a normal object for its class. Its luminosity in terms of the primary was determined from the combined spectrum of the two stars, in which the metallic lines and the $K$ line of calcium are weaker than normal, and the wings of the Balmer hydrogen are stronger. The assumption that the primary obeys the mass-luminosity relation-mass proportional to absolute magnitude--made it possible to determine the masses and mean densities of both stars. Many other binary systems exist in which the components are $G$ - and $A$-type, and the investigation of these systems is important that more may be understood about the relationship of the sub-dwarfs to the white dwarfs.

\section{A Radio'ogical Library}

A RADIOLOGrCal library valued at $£ 3,500$ is on sale by the Museum Book Store, 45 Museum Street, W.C.1, by whom a 12-page pamphlet is issued. This world-wide collection of journals and periodical publications, each in the language of its origin, is not likely to be duplicated, and it is hoped that it will find its way into some research laboratory or radiological centre. The chief publishers of radiological subjects have been the United States, Germany, France and Great Britain, and we can think of no X-ray or radium journal which is not included in this library. This offer of sale has now been open for some months and the step of acquiring the valuable collection waits to be taken by some authority with vision as well as money.

\section{Prof. F. H. Garner}

THE chair of oil engineering and refining in the University of Birmingham, rendered vacant by the death of Prof. A. W. Nash, has been filled by the appointment of Dr. F. H. Garner, a graduate of the University (1914). Dr. Garner was for many years chief chemist of the Anglo-American Oil Co. and is that company's principal scientific officer in Great Britain; he has a high reputation and an excellent record as a research chemist in the field of oil chemistry. He has acted as an external examiner in the Oil Engineering Department of the University of Birmingham for several years and has thus a knowledge of the working of the Department.

\section{Announcements}

THE Emil von Behring prize, which is awarded by the University of Marburg every two years for outstanding achievements in immunology, serum therapy and chemotherapy, has been awarded to Prof. Paul Uhlenhuth, professor of hygiene and bacteriology in the University of Freiburg-im-Breisgau.

WE have received Abstracts of Articles and Patents on the Production of Glycerol by Fermentation published by the National Research Council of Canada, Ottawa, 1942, which contains abstracts of 109 articles and 114 patents on this subject. The publication is N.R.C., No. 1070 , price 50 cents. 